Article

\title{
Biotransformation with a New Acinetobacter sp. Isolate for Highly Enantioselective Synthesis of a Chiral Intermediate of Miconazole
}

\author{
Yanfei Miao, Yuewang Liu, Yushu He and Pu Wang *(D) \\ College of Pharmaceutical Science, Zhejiang University of Technology, Hangzhou 310014, China; \\ miaoyanfeizjut@163.com (Y.M.); liuyuewangzjut@163.com (Y.L.); heyushuzjut@163.com (Y.H.) \\ * Correspondence: wangpu@zjut.edu.cn; Tel.: +86-571-88320389
}

Received: 30 April 2019; Accepted: 15 May 2019; Published: 20 May 2019

check for updates

\begin{abstract}
R)-2-Chloro-1-(2,4-dichlorophenyl) ethanol is a chiral intermediate of the antifungal agent Miconazole. A bacterial strain, ZJPH1806, capable of the biocatalysis of 2-chloro-1-(2,4-dichlorophenyl) ethanone, to $(R)$-2-chloro-1-(2,4-dichlorophenyl) ethanol with highly stereoselectivity was isolated from a soil sample. It was identified as the Acinetobacter sp., according to its morphological observation, physiological-biochemical identification, and $16 S$ rDNA sequence analysis. After optimizing the key reaction conditions, it was demonstrated that the bioreduction of 2-chloro-1-(2,4-dichlorophenyl) ethanone was effectively transformed at relatively high conversion temperatures, along with glycerol as cosubstrate in coenzyme regeneration. The asymmetric reduction of the substrate had reached $83.2 \%$ yield with an enantiomeric excess (ee) of greater than $99.9 \%$ at $2 \mathrm{~g} / \mathrm{L}$ of 2-chloro-1-(2,4-dichlorophenyl) ethanone; the reaction was conducted at $40{ }^{\circ} \mathrm{C}$ for $26 \mathrm{~h}$ using resting cells of the Acinetobacter sp. ZJPH1806 as the biocatalyst. The yield had increased by nearly 2.9 -fold (from $28.6 \%$ to $83.2 \%$ ). In the present study, a simple and novel whole-cell-mediated biocatalytic route was applied for the highly enantioselective synthesis of ( $R$ )-2-chloro-1-(2,4-dichlorophenyl) ethanol, which allowed the production of a valuable chiral intermediate method to be transformed into a versatile tool for drug synthesis.
\end{abstract}

Keywords: (R)-2-chloro-1-(2,4-dichlorophenyl) ethanol; whole-cell catalysis; Acinetobacter sp.; isolation; $(R)$-miconazole

\section{Introduction}

Azoles have been widely performed in the treatment of immunocompromised patients suffering from undergoing invasive surgery or AIDS, graft reception, or anti-cancer therapy [1]. Pharmacological studies have found that some of the antifungal activity of $R$-enantiomer is superior to that of the corresponding $S$-isomer and its racemate, such as sertaconazole, which can significantly improve drug efficacy [2]. Miconazole is a broad-spectrum antifungal agent and its mechanism of action is to inhibit ergosterol biosynthesis and cause toxic methylated sterol levels, thereby inhibiting the growth of fungi [3]. (R)-miconazole (Figure 1) appeared to account for a greater degree of the biological activity than did racemic miconazole [2]. (R)-2-Chloro-1-(2,4-dichlorophenyl) ethanol is applied in the synthesis of many antifungal intermediates, such as miconazole, econazole, and sertaconazol. Thus, it is necessary to focus on the synthesis of $(R)$-2-chloro-1-(2,4-dichlorophenyl) ethanol in the preparation of $(R)$-miconazole. 


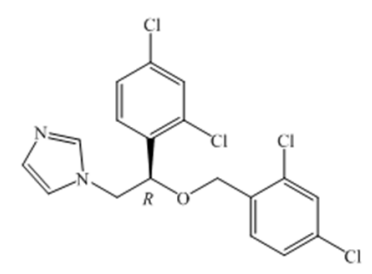

Figure 1. Structure of $R$-Miconazole.

To replace the above racemates, single enantiomers can be produced by chemical methods. de Mattos reported that rhodium, ruthenium, and iridium were the most popular catalysts in the hydrogenation of ketones. Sharpless dihydroxylation and oxazaborolidine catalysts were also used to synthesize enantiomerically enriched single enantiomers [4]. Zhang sought to provide an industrialized production method for $(R)$-2-chloro-1-(2,4-dichlorophenyl) ethanol using borane complexes and diphenyl proline in organic solvents, with 2-chloro-1-(2,4-dichlorophenyl) ethanone as the substrate; the reaction was able to achieve a yield of $92.4 \%$ with $99.3 \%$ enantiomeric excess (ee) [5]. Luo et al. presented their chemical method using ruthenium and (1S, 2S)-(+)-N-(4-toluenesulfonyl)-1, 2-diphenylethylenediamine to reduce 2-chloro-1-(2,4-dichlorophenyl) ethanone, achieving $96.4 \%$ yield and $99.2 \%$ ee [6]. The enantioselectivity of the product is related to the complexity of the ligands. Some transition metals need additional enantiomeric ligands to achieve high enantioselectivity, and the cost of transition metals limit the use of industrialization processes [7].

The asymmetric reduction of prochiral ketones is considered as an essential technique in preparing optically active compounds [8]. Numerous works have been studied concerning the preparation of single enantiomers employing biocatalysis in the culturing of plant, yeast, and bacterial products, which mostly focus on the preparation of $R$-configuration [9-11]. The biological process for the production of (R)-2-chloro-1-(2,4-dichlorophenyl)-ethanol was also reported. JuanMangas-Sanchez related that commercially available purified alcohol dehydrogenase $\mathrm{ADH} A$, using NADH as cofactor, can convert $1.0 \mathrm{mM} 2$-chloro-1-(2,4-dichlorophenyl) ethanone in $24 \mathrm{~h}$ with a yield of $74 \%$. Under the same conditions, ADH T used expensive NADPH as cofactor, and the yield was more than 99\% [2]; additionally, Tang et al. employed an enzymatic reduction process to produce ( $R$ )-2-chloro-1-(2,4-dichlorophenyl) ethanol by the recombinant expression of Candida macedoniensis AKU 4588, with the ee value they attained being 99\% [12]; Yue-Peng Shang explored some technique without using additional cofactors, demonstrating that a ketoreductase from Scheffersomyces stipitis CBS 6045, SsCR, in lyophilized cells was able to reduce $67 \mathrm{~g} / \mathrm{L}$ 2-chloro-1-(2,4-dichlorophenyl) ethanone, at $88.2 \%$ yield and 99.9\% ee [7]. Biocatalysts took advantage of high chemo-, regio-, unsurpassed selectivity and observed the green principles [13].

However, current reports on the synthesis of (R)-2-chlorophenyl-(2,4-dichlorophenyl) ethanol are mainly focused on chemical and pure enzyme synthesis [12]. Whole-cell catalysis, rather than purified enzymes, may be more suitable for the large-scale production, because microbial whole-cells used in production as catalysts contain multiple active enzymes and better protects desired enzymes against inactivation. Therefore, whole-cell biocatalysis provides an attractive alternative to selectively producing corresponding single enantiomers. In addition, the advantage of the in situ recycle of cofactors reduces the process cost, making it an increasingly attractive method for biocatalysis [14-16]. In the present study, isolated ZJPH1806 was employed as a whole-cell biocatalyst in the asymmetric bioreduction of 2-chloro-1-(2,4-dichlorophenyl) ethanone to ( $R$ )-2-chloro-1-(2,4-dichlorophenyl) ethanol in an aqueous medium using glycerol $20 \%(w / v)$ as cosubstrate; Acinetobacter sp. ZJPH1806 was maintained at an enantiomeric excess (ee) of greater than $99.9 \%$ (Figure 2). The effects of some key reaction parameters were studied to increase the yield for the production of single enantiomer alcohol. The strain identified as Acinetobacter sp. ZJPH1806 had been newly isolated from a soil sample for the enantioselective preparation of (R)-2-chloro-1-(2,4-dichlorophenyl) ethanol. The strain exhibited excellent enantioselectivity and thermotolerance at a wide catalytic range during enantiopure 
alcohol synthesis. Thermotolerant carbonyl reductase is a promising biocatalyst for single enantiomers production and is consequently beneficial for industrial scale manufacturing.

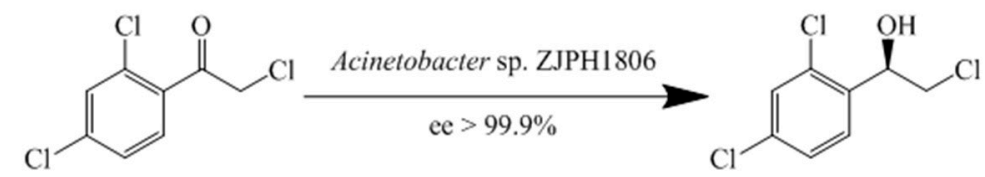

2-Chloro-1-(2, 4-dichlorophenyl) ethanone

(R)-2-Chloro-1-(2, 4-dichlorophenyl) ethanol

Figure 2. Asymmetric synthesis of (R)-2-chloro-1-(2,4-dichlorophenyl) ethanol.

\section{Results}

\subsection{The Isolation of Strains for the Production of (R)-2-chloro-1-(2,4-dichlorophenyl) Ethanol}

A variety of microorganisms including bacteria, yeasts, and molds were isolated from the soil in order to obtain strains with excellent catalytic performance. Nine strains were thus discovered, which displayed the required product yield. Among these, strain ZJPH1806 demonstrated a powerful enantioselectivity and yield (Table 1). The results, determined through the use of high-performance liquid chromatography (HPLC), are displayed in Figure S1.

Table 1. The results of the screening strain.

\begin{tabular}{cccc}
\hline Strain & Yield (\%) & ee (\%) & Stereoselectivity \\
\hline NB1-2 & 17.9 & 57.1 & $S$ \\
CP2-3 & 23.4 & 79.6 & $S$ \\
SX4-7 & 15.8 & 99.9 & $S$ \\
BJ-1 & 9.0 & 72.1 & $S$ \\
AF-4 & 20.1 & 54.3 & S \\
JX1-3 & 23.9 & 59.0 & $R$ \\
HZ1-6 & 12.1 & 99.9 & $R$ \\
XM1-1 & 15.0 & 99.9 & $R$ \\
ZJPH1806 & 28.6 & 99.9 & $R$ \\
\hline
\end{tabular}

\subsection{Identification and Characterization of Strain ZJPH1806}

Following cultivation on nutrient agar plate for three days at $30{ }^{\circ} \mathrm{C}$, the isolate, ZJPH1806, grew white colonies with diameters of around $0.2 \mathrm{~cm}$. Physiological-biochemical identification results revealed that the species can use the tyrosine aromatic amine enzyme, citrate (Na), to alkalize $L$-lactate and succinate. The colony morphology of ZJPH1806 was illustrated in Figure S2.

The partial 165 rDNA sequence of ZJPH1806 (1467 bp) was determined and deposited in the GenBank database (Accession no. MK784893), and related species of similar DNA sequence were selected for the conduction of a homologous analysis with strain ZJPH1806. The phylogenetic tree of Acinetobacter sp. ZJPH1806, based on 16S rDNA sequencing, is shown in Figure S3. Strain ZJPH1806 had the highest homology with Actinetobacter sp. PAMU-1.11 (GenBank Accession no. 44885679), sharing a high sequence identity of $95 \%$. Based on the results of phylogenetic analysis and morphological characterization, this wild strain was named Acinetobacter sp. ZJPH1806 and preserved in the China Centre for Type Culture Collection (CCTCC), with the Accession code of CCTCC M 2019214.

\subsection{The Growth Curve of Acinetobacter sp. ZJPH1806}

The enzyme production conditions of Acinetobacter sp. ZJPH1806 were optimized. The composition of the optimized medium was $27.63 \mathrm{~g} / \mathrm{L}$ glucose, $57.35 \mathrm{~g} / \mathrm{L}$ corn steep liquor, and $0.9 \mathrm{~g} / \mathrm{L} \mathrm{KH}_{2} \mathrm{PO}_{4}$, $\mathrm{pH}$ 8.0. The inoculation amount was $6 \%$ at $250 \mathrm{~mL}$, with the Erlenmeyer flasks containing $90 \mathrm{~mL}$ of fermentation medium and cultured for $24 \mathrm{~h}$ on a rotary shaker at $30^{\circ} \mathrm{C}$ and $200 \mathrm{rpm}$. The curves 
of growth and enzyme production of the strain were displayed in Figure 3. The ${ }^{1} \mathrm{H}$ NMR nuclear magnetic spectrum of product is shown in Figure 4, and the substrate's spectrum is shown in Figure S4.

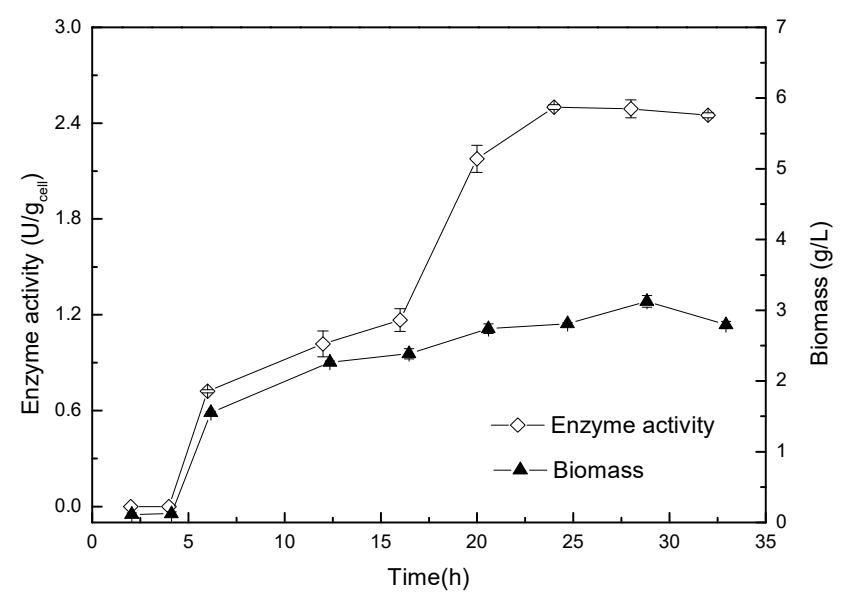

Figure 3. Curves of growth and enzyme production for Acinetobacter sp. ZJPH1806.

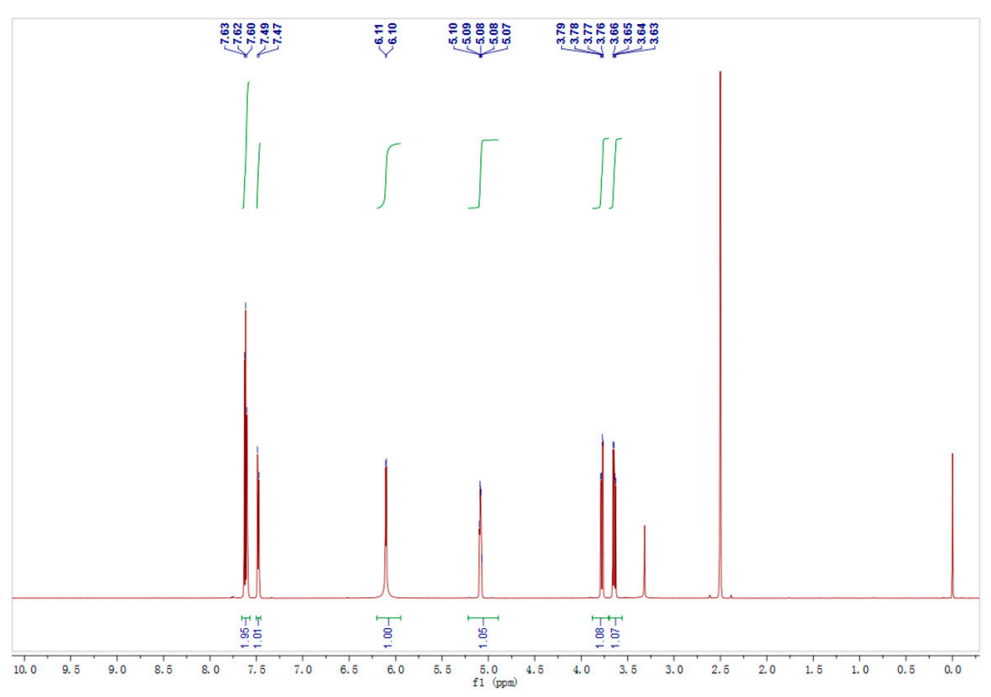

Figure 4. The ${ }^{1} \mathrm{H}$ NMR spectrum of the product.

It can be concluded from Figure 3 that the strain was in a lag phase within $4 \mathrm{~h}$, with a 5 to $15 \mathrm{~h}$ logarithmic growth period, then entered a stable phase after $24 \mathrm{~h}$, at which time the enzymatic activity and biomass of the bacterial strain had stabilized.

\subsection{The Cosubstrate-Coupled System for Cofactors Regeneration}

The cosubstrate-coupled, enzyme-coupled, photochemical, and electrochemical approaches are the most effective means by which the cofactors (especially NAD $(\mathrm{H})$ and NADP $(\mathrm{H})$ ) can be regenerated in asymmetric biological reduction reactions [17]. Cosubstrate coupling was considered the method of choice. Its advantages were its low cost and ease of operation. The study selected several sugars and alcohols, including glucose, maltose, sucrose, glycerol, alcohol, methanol, and isopropanol, as cosubstrates for coenzyme regeneration (Table 2). It was indicated that glycerol reached the highest yield at $50.1 \%$, significantly higher than the control (at a 32.6\% yield). Enantioselectivity remained above $99.9 \%$. 
Table 2. Effect of different cosubstrates on the asymmetric reduction.

\begin{tabular}{ccc}
\hline Cosubstrate & Yield (\%) & ee (\%) \\
\hline Glucose & 49.4 & 99.9 \\
Sucrose & 40.6 & 99.9 \\
Maltose & 48.6 & 99.9 \\
Glycerol & 50.1 & 99.9 \\
Alcohol & 33.3 & 99.9 \\
Isopropanol & 40.4 & 99.9 \\
Methanol & 9.6 & 99.9 \\
Control & 32.6 & 99.9 \\
\hline
\end{tabular}

Various glycerol concentrations, ranging from $5 \%$ to $25 \%(w / v)$, were used to improve the asymmetric reduction of 2-chloro-1-(2,4-dichlorophenyl) ethanone to (R)-2-chloro-1- (2,4-dichlorophenyl) ethanol with the Acinetobacter sp. ZJPH1806 as biocatalyst. As shown in Figure 5, the yield rose remarkably with an increase in the glycerol concentration of up to $20 \%(w / v)$. Following that, the concentration of glycerol was further increased, decreasing the efficiency of the reaction. This reduction may be due to glycerol's high viscosity causing problems in transfer efficiency [18]. Asami's results coincide with the above research, in that glycerol can be used to regenerate cofactors in the bioreduction of 1-[3,5-bis(dimethylcarbamoyloxy)phenyl]-2-chloroethanone by Williopsis californica JCM 3600 [19].

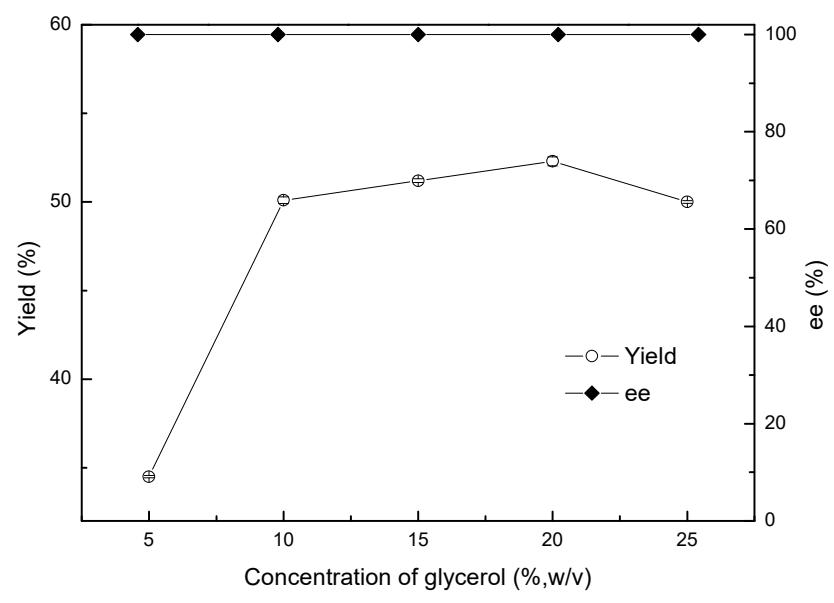

Figure 5. Effect of different glycerol addition on the asymmetric reduction.

2.5. The Effects of Buffer $p H$ and Ionic Strength on the Asymmetric Reduction of 2-chloro-1-(2,4-dichlorophenyl) Ethanone

Varying the $\mathrm{pH}$ of the reaction system affects the permeability of the cell membrane, and the dissociation state of the groups necessary for the enzyme activity center and substrate, thus affecting the catalytic activity, stereoselectivity, and catalytic efficiency of the enzyme [20]. In this experimental design, the Acinetobacter sp. ZJPH1806 mediated reduction of 2-chloro-1-(2,4-dichlorophenyl) ethanone was investigated at different buffer $\mathrm{pH}$ levels within the range of 6.0 to 8.0. The results are shown in Table 3 . Stereoselectivity remained above $99.9 \%$ within this range, but the yield was greatly affected. The yield was $56.2 \%$ when the $\mathrm{pH}$ was 7.6 , but it did not significantly improve when the ionic strength of the phosphate buffer was changed from 0.05 to $0.2 \mathrm{M}$ at the same $\mathrm{pH}$ of 7.6, indicating that Acinetobacter sp. ZJPH1806 can adapt to a wide range of ionic phosphate strengths. Reduction could maintain a high yield and ee value under relatively wide $\mathrm{pH}$ conditions. This differed strikingly from Guo's account in which the optimized pH with Acinetonacter sp. SC13874 was 5.5 with $0.1 \mathrm{M}$ potassium phosphate [21]. 
Table 3. Effect of buffer $\mathrm{pH}$ on the asymmetric reduction.

\begin{tabular}{cccc}
\hline & Buffer Solution Condition & Yield (\%) & ee (\%) \\
\hline \multirow{3}{*}{ 6.0, 0.1 M } & 10.4 & 99.9 \\
$\mathrm{pH}^{\mathrm{a}}$ & $6.4,0.1 \mathrm{M}$ & 37.8 & 99.9 \\
& $6.8,0.1 \mathrm{M}$ & 53.3 & 99.9 \\
& $7.2,0.1 \mathrm{M}$ & 55.3 & 99.9 \\
$7.6,0.1 \mathrm{M}$ & 56.2 & 99.9 \\
& $8.0,0.1 \mathrm{M}$ & 50.1 & 99.9 \\
\hline \multirow{2}{*}{$\mathrm{pH} 7.6$} & $7.6,0.05 \mathrm{M}$ & 55.8 & 99.9 \\
& $7.6,0.2 \mathrm{M}$ & 55.0 & 99.9 \\
\hline \multicolumn{4}{c}{}
\end{tabular}

\subsection{The Effect of Temperature on the Asymmetric Reduction of 2-chloro-1-(2,4-dichlorophenyl) Ethanone}

Temperature, likewise, plays an important role in catalytic reduction mediated by microbial cells, including by affecting the activity of catalysts, the stability of enzyme production, reaction stereoselectivity, and the equilibrium constant [22]. The carbonyl reductase in ZJPH806 was expected to be a heat-resistant enzyme with good performance in biological reduction involving 2-chloro-1-(2,4-dichlorophenyl) ethanol in the interest of achieving a technical breakthrough in the heat-resistant transformation of Acinetobacter sp. Therefore, the effect of different reaction temperatures ranging from 25 to $50{ }^{\circ} \mathrm{C}$ on yield and enantioselectivity was subsequently investigated, and the results displayed in Figure 6. As expected, the yield decreased slightly at higher reaction temperatures $\left(40-50{ }^{\circ} \mathrm{C}\right)$. The maximum yield of $59.3 \%$ was obtained at $40{ }^{\circ} \mathrm{C}$ with a product ee greater than $99.9 \%$ at $2 \mathrm{~g} / \mathrm{L}$ for 2-chloro-1-(2,4-dichlorophenyl) ethanone.

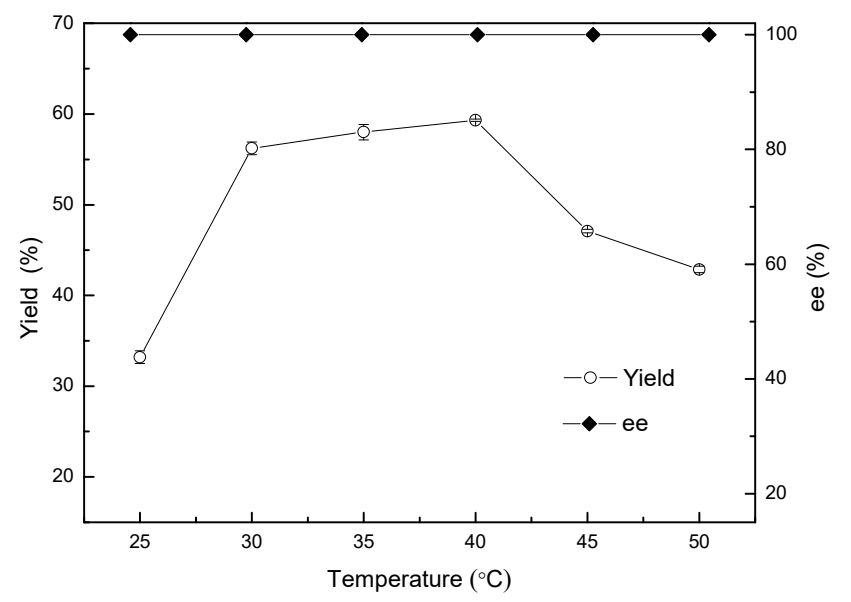

Figure 6. Effect of temperature on the asymmetric reduction.

\subsection{Effects of Cell Concentration, Substrate Concentration, and Reaction Time on Biocatalytic Reduction}

In biocatalytic reactions, increasing cell concentration can make a great difference on the product yield [20]. At a certain point, with an increase in cell concentration, the amount of enzyme provided also increases, which is conducive to the progress of the reaction and the improvement of the yield. However, cell oxygen consumption also increases simultaneously, with the metabolites produced by cell metabolism likewise increasing within a short period, leading conversely to a decrease in the yield. Therefore, addition of the appropriate cell concentration plays an important role in improving the yield of the reaction. Thus, cell concentrations varying from 50 to $300 \mathrm{~g} / \mathrm{L}$ (wet cell weight) were designed in order to ascertain the optimum concentration for the bioreduction of 2-chloro-1-(2,4-dichlorophenyl) ethanone to $(R)$-2-chloro-1-(2,4-dichlorophenyl) ethanol. The results revealed that the maximal yield for $(R)$-form ethanol reached $76.6 \%$ at $150 \mathrm{~g} / \mathrm{L}$ wet cell weight (approximately $26.7 \mathrm{~g} / \mathrm{L}$ dry cell concentration) 
with $>99.9 \%$ of product ee. However, a further increase in the wet cell concentration resulted in a significant decrease in the yield. The ee value of the product remained optimal (Figure 7a).

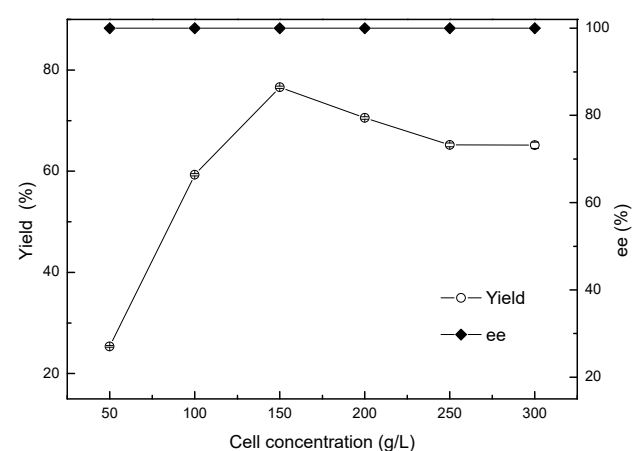

(a)

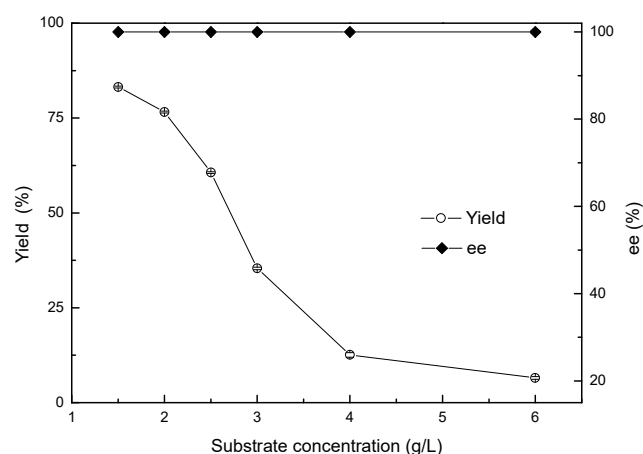

(b)

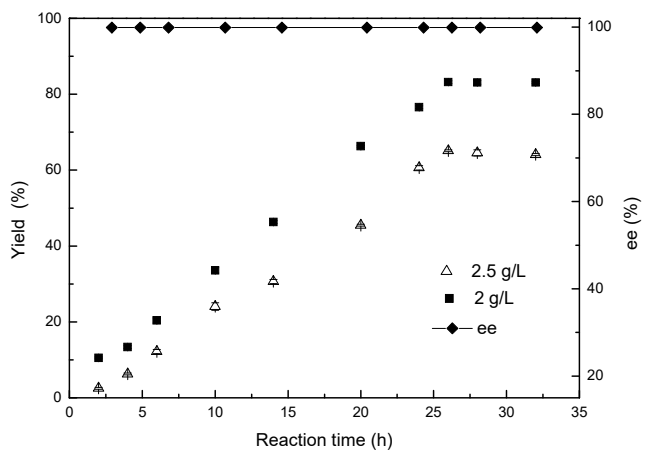

(c)

Figure 7. Effects of cell concentration (a), substrate concentration (b), and reaction time (c) on the asymmetric reduction.

In order to evaluate the ZJPH1806 cells mediated biological capacity, 2-chloro-1-(2,4dichlorophenyl) ethanone was used with different concentrations of 1.5 to $6.0 \mathrm{~g} / \mathrm{L}$ to examined the effect of substrate concentration on the synthesis of (R)-2-chloro-1-(2,4-dichlorophenyl) ethanol. Figure $7 \mathrm{~b}$ demonstrates the results, with $83.2 \%$ yield being achieved within $24 \mathrm{~h}$ at $1.5 \mathrm{~g} / \mathrm{L}$ of 2-chloro-1-(2,4-dichlorophenyl) ethanone concentration. This paper attempted to increase the substrate concentration, causing a reduction in the yield. This may be due to the existence of toxicity of substrates and products to cells and enzymes [23]. When the substrate concentration was increased to $2 \mathrm{~g} / \mathrm{L}$, the yield reached $83.2 \%$ when the reaction time was extended to $26 \mathrm{~h}$, while the yield was only $65.12 \%$ at $2.5 \mathrm{~g} / \mathrm{L}$ of substrate concentration (Figure 7c).

\section{Discussion}

Biocatalysts have been gradually introduced into the medical field. The biocatalytic method has attracted significant attention due to its mild reaction conditions, fewer by-products, and reduced pollution from biodegradability [24]. Zhu's report used alcohol dehydrogenase from Pyrococcus furiosus (PFADH), with a substrate concentration of $250 \mathrm{mM}$ 2-chloro-1-(2,4-dichlorophenyl) ethanone, the yield up to $92 \%$, and $99 \%$ ee [25]. This route was dependent on NADH addition. Compared with the use of purified enzymes, whole-cell biocatalysis does not require additional cofactors and is in favor of maintaining the stability of intracellular enzymes [26]. In this study, whole cells were used as biocatalysts to produce ( $R$ )-2-chloro-1-(2,4-dichlorophenyl) ethanol, the key chiral intermediate in chiral miconazole production. The strain ZJPH1806 was obtained by screening soil samples with 
perfect enantioselectity. Based on its morphology, physiological-biochemical identification and $16 S$ rDNA sequence analysis results identified the strain as an Acinetobacter sp. The key factors affecting the yield and ee value were optimized, with the results demonstrating that the yield reached $83.2 \%$ in $26 \mathrm{~h}$ at $2 \mathrm{~g} / \mathrm{L}$ of substrate concentration, which significantly improved the yield prior to optimization.

Some reports concern the synthesis of single enantiomers by using Acinetobacter sp. as a biocatalyst and proved that Acinetobacter sp. has a good potential in biocatalysis applications. Acinetobacter sp. SC13874 contained ketoreductase I, ketoreductase II, and ketoreductase III [21]. Among them, purified ketoreductase III was able to asymmetrically catalyze the transformation of ethyl 3,5-diketo-6-benzyloxyhexanoate to syn-(3R, 5S)-dihydroxy ester with absolute stereoselectivity and a yield of $99.3 \%$. A diketoreductase (DKR), cloned from Acinetobacter baylyi ATCC 33305, was also used to reduce these two carbonyl groups via the addition of NADH with more than $99.5 \%$ ee. In $0.1 \mathrm{M}$ potassium phosphate buffer, the ketoreductase III showed the $\mathrm{pH}$ optimum centered at $\mathrm{pH}$ 7.0, and the DKR was pH 6.0 $[27,28]$. The $\mathrm{pH}$ of the reduction of ketones catalyzed differs from that of Acinetobacter sp. ZJPH1806 under alkaline conditions. It is observed that Acinetobacter sp. ZJPH1806 possesses a wide catalytic range for asymmetric reduction because the yield was not significantly influenced by the $\mathrm{pH}$ and ionic strength of the phosphate buffer under the tested range. Furthermore, within the tested range $\left(40-50^{\circ} \mathrm{C}\right)$, the species also maintained high catalytic capacity. For industrial biocatalysis, novel biocatalysts with eminent biochemical properties such as thermostability and $\mathrm{pH}$ stability have, therefore, become increasingly attractive [29].

\section{Materials and Methods}

\subsection{Materials}

2-Chloro-1-(2,4-dichlorophenyl) ethanone ( $\geq 99 \%$ purity) and ( $R$ )-2-chloro-1-(2,4-dichlorophenyl) ethanol ( $\geq 98 \%$ purity) were purchased from Hangzhou Xinhai Biological Co., Ltd., China. Soil samples were collected from different areas of China, such as Fujian, Shanxi, and Zhejiang Province. Acinetobacter sp. ZJPH1806 was isolated from a soil sample collected in Jinghua, Zhejiang Province, China. All other chemicals were obtained commercially and were of analytical grade or better.

\subsection{Screening and Cultivation of the Microorganisms}

One gram of soil sample was added to $100 \mathrm{~mL}$ of normal saline $(0.85 \%, w / v)$ and vibrated for $30 \mathrm{~min}$. Subsequently, $1 \mathrm{~mL}$ of the turbid bacterial solution was added to a seeding solution and cultured it for 24 $\mathrm{h}$. The seeding solution contained $15 \mathrm{~g} / \mathrm{L}$ glucose, $20 \mathrm{~g} / \mathrm{L}$ peptone, $10 \mathrm{~g} / \mathrm{L}$ yeast extract, $2 \mathrm{~g} / \mathrm{L}\left(\mathrm{NH}_{4}\right)_{2} \mathrm{SO}_{4}$, $2 \mathrm{~g} / \mathrm{L} \mathrm{KH}_{2} \mathrm{PO}_{4}, 1 \mathrm{~g} / \mathrm{L} \mathrm{NaCl}$, and $0.5 \mathrm{~g} / \mathrm{L} \mathrm{MgSO}{ }_{4} \cdot 7 \mathrm{H}_{2} \mathrm{O}$ in $\mathrm{pH}$ 6.5. 2-Chloro-1-(2,4-dichlorophenyl) ethanone was used as the sole carbon source in the screening medium to select the best microorganisms and was incubated at $30{ }^{\circ} \mathrm{C}$ and $200 \mathrm{rpm}$ for 5-7 days. The screening medium contained $2 \mathrm{~g} / \mathrm{L}$ $\left(\mathrm{NH}_{4}\right)_{2} \mathrm{SO}_{4}, 2 \mathrm{~g} / \mathrm{L} \mathrm{KH}{ }_{2} \mathrm{PO}_{4}, 1 \mathrm{~g} / \mathrm{L} \mathrm{NaCl}, 0.5 \mathrm{~g} / \mathrm{L} \mathrm{MgSO} 4 \cdot 7 \mathrm{H}_{2} \mathrm{O}$, and $2 \mathrm{~g} / \mathrm{L}$ 2-chloro-1-(2,4-dichlorophenyl) ethanone. The enriched culture was obtained and diluted to $10^{-4}, 10^{-5}$, and $10^{-6}$, respectively. The diluents $(200 \mu \mathrm{L})$ were respectively plated over the screening medium agar $\left(2 \mathrm{~g} / \mathrm{L}\left(\mathrm{NH}_{4}\right)_{2} \mathrm{SO}_{4}, 2 \mathrm{~g} / \mathrm{L}\right.$ $\mathrm{KH}_{2} \mathrm{PO}_{4}, 1 \mathrm{~g} / \mathrm{L} \mathrm{NaCl}, 0.5 \mathrm{~g} / \mathrm{L} \mathrm{MgSO} \cdot 7 \mathrm{H}_{2} \mathrm{O}, 2 \mathrm{~g} / \mathrm{L}$ 2-chloro-1-(2,4-dichlorophenyl) ethanone, and $20 \mathrm{~g} / \mathrm{L}$ agar, $\mathrm{pH}$ 6.5), and then incubated at $30{ }^{\circ} \mathrm{C}$ and $200 \mathrm{rpm}$ for 5-7 days. Following maturation, the pure colonies were obtained by continuous streaking of single colonies onto agar plates with all nutrition culture mediums (15 g/L glucose, $20 \mathrm{~g} / \mathrm{L}$ peptone, $10 \mathrm{~g} / \mathrm{L}$ yeast extract, $2 \mathrm{~g} / \mathrm{L}\left(\mathrm{NH}_{4}\right)_{2} \mathrm{SO}_{4}, 2 \mathrm{~g} / \mathrm{L} \mathrm{KH}_{2} \mathrm{PO}_{4}$, $1 \mathrm{~g} / \mathrm{L} \mathrm{NaCl}, 0.5 \mathrm{~g} / \mathrm{L} \mathrm{MgSO}{ }_{4} \cdot 7 \mathrm{H}_{2} \mathrm{O}$, and $20 \mathrm{~g} / \mathrm{L}$ agar, $\mathrm{pH}$ 6.5) at $30{ }^{\circ} \mathrm{C}$ for $2-3$ days.

The single colonies were inoculated into $100 \mathrm{~mL}$ seed medium of $250 \mathrm{~mL}$ shaken flasks and incubated at $30^{\circ} \mathrm{C}, 200 \mathrm{rpm}$ for $12 \mathrm{~h}$. Then, $10 \mathrm{~mL}$ of inoculum was transferred into $100 \mathrm{~mL}$ fermentation medium of $250 \mathrm{~mL}$ Erlenmeyer flasks ( $15 \mathrm{~g} / \mathrm{L}$ glucose, $20 \mathrm{~g} / \mathrm{L}$ peptone, $10 \mathrm{~g} / \mathrm{L}$ yeast extract, $2 \mathrm{~g} / \mathrm{L}$ $\left.\left(\mathrm{NH}_{4}\right)_{2} \mathrm{SO}_{4}, 2 \mathrm{~g} / \mathrm{L} \mathrm{KH}_{2} \mathrm{PO}_{4}, 1 \mathrm{~g} / \mathrm{L} \mathrm{NaCl}, 0.5 \mathrm{~g} / \mathrm{L} \mathrm{MgSO}_{4} \cdot 7 \mathrm{H}_{2} \mathrm{O}, \mathrm{pH} 6.5\right)$, and further incubated at $30{ }^{\circ} \mathrm{C}$ and $200 \mathrm{rpm}$ for $24 \mathrm{~h}$. 


\subsection{Phenotypic Characterization of Isolate ZJPH1806}

The morphological characterization of strain ZJPH1806 was observed following the incubation on the nutrient agar plates. Physiological-biochemical identification was performed by a standardized method employing the VITEK 2 compact GN system (bioMérieux, France).

\section{4. $16 \mathrm{~S}$ rDNA Sequence Determination and Phylogenetic Analysis}

The taxonomic identification of strain ZJPH1806 was performed through partial $16 S$ rDNA sequence determination using a SK8255 column bacterial genomic DNA extraction kit, and 165 rDNA was amplified by PCR. The extracted whole cell genomes were amplified by PCR with the universal primer 27F: (5'-AGTTTGATCMTGGCTCAG-3') and 1429R: (5'-GGTTACCTTGTTACGACTT-3'). The PCR amplification conditions were as follows: $94{ }^{\circ} \mathrm{C}$ for $4 \mathrm{~min}$, repeated for 30 cycles of $45 \mathrm{~s}$ at $9{ }^{\circ} \mathrm{C}, 55^{\circ} \mathrm{C}$ for $45 \mathrm{~s}, 72{ }^{\circ} \mathrm{C}$ for $1 \mathrm{~min}$, and a final extension step of $72{ }^{\circ} \mathrm{C}$ for $10 \mathrm{~min}$. The resulting approximately $1467 \mathrm{bp}$ PCR products were purified and sequenced by Sangon Biotech Co., Ltd. For the homologous analysis, related sequences with high degrees of similarity were found through the GenBank database (National Center for Biotechnology Information, NCBI). A neighbor-joining phylogenetic tree with a nucleotide distance model and a bootstrap analysis for the evolution of the phylogenetic topology was constructed with MEGA Version 6.0.

\subsection{The Growth Curve of Acinetobacter sp. ZJPH1806}

The cells were cultured in seeding liquid at $200 \mathrm{rpm}$ and $30{ }^{\circ} \mathrm{C}$ for $12 \mathrm{~h}$; then, they were inoculated into an optimized fermentation medium $(27.63 \mathrm{~g} / \mathrm{L}$ glucose, $57.35 \mathrm{~g} / \mathrm{L}$ corn steep liquor, and $0.9 \mathrm{~g} / \mathrm{L}$ $\mathrm{KH}_{2} \mathrm{PO}_{4}, \mathrm{pH} 8.0$ ), and their biomass and enzymatic activity were measured.

\subsection{Asymmetric Bioreduction Process}

After culture fermentation, the bioreduction was performed in $50 \mathrm{~mL}$ Erlenmeyer flasks with $10 \mathrm{~mL}$ of phosphate buffer [0.1 M, pH 6.5, DMSO $(10 \%, v / v)], 100 \mathrm{~g} / \mathrm{L}$ cells (wet cell weight), $2 \mathrm{~g} / \mathrm{L}$ 2-chloro-1-(2,4-dichlorophenyl) ethanone, and $100 \mathrm{~g} / \mathrm{L}$ glucose. The samples at conditions of asymmetric reduction were vibrated at $200 \mathrm{rpm}$ and $30^{\circ} \mathrm{C}$ for $24 \mathrm{~h}$. The product was extracted with ethyl acetate for $30 \mathrm{~min}$. All bioconverted samples were carried out in triplicate for detection. The yield and product ee were assayed by HPLC analysis.

\subsection{Analytical Methods}

Biomass was assayed by densitometry. Cell growth was monitored on a spectrophotometer (model UV-16-1; Shimadzu, Japan) at a wavelength of $600 \mathrm{~nm}$. One unit of enzyme activity was defined as the amount of enzyme needed to produce $1 \mu \mathrm{mol}$ of $(R)$-2-chloro-1-(2,4-dichlorophenyl) ethanol per minute under the assay conditions.

The NMR spectra of the substrate and product were detected by a method using a Bruker spectrometer (Ascend ${ }^{\mathrm{TM}}$; Bruker Ltd., Germany). The product was recovered by ethyl acetate extraction and purified by column chromatography on silica gel. (R)-2-Chloro-1-(2,4-dichlorophenyl) ethanol: ${ }^{1} \mathrm{H}$ NMR $(600 \mathrm{MHz}, \mathrm{DMSO}): 87.66-7.57(\mathrm{~m}, 2 \mathrm{H}), 7.48(\mathrm{~d}, \mathrm{~J}=8.4 \mathrm{~Hz}, 1 \mathrm{H}), 6.10(\mathrm{~d}, \mathrm{~J}=4.9 \mathrm{~Hz}$, $1 \mathrm{H}), 5.08(\mathrm{dt}, \mathrm{J}=7.8,4.0 \mathrm{~Hz}, 1 \mathrm{H}), 3.78(\mathrm{dd}, \mathrm{J}=11.3,3.8 \mathrm{~Hz}, 1 \mathrm{H}), 3.64(\mathrm{dd}, \mathrm{J}=11.3,6.9 \mathrm{~Hz}, 1 \mathrm{H}) .{ }^{13} \mathrm{C} \mathrm{NMR}$ (151 MHz, DMSO): 8138.39 (s), 132.90 (s), 131.97 (s), 129.87 (s), 128.44 (s), 127.44 (s), 68.75 (s), 48.48 (s). 2-Chloro-1-(2,4-dichlorophenyl) ethanone: ${ }^{1} \mathrm{H}$ NMR (600 MHz, DMSO) $87.82(\mathrm{dd}, \mathrm{J}=3.2,5.2 \mathrm{~Hz}, 2 \mathrm{H})$, $7.61(\mathrm{dd}, \mathrm{J}=8.4,2.0 \mathrm{~Hz}, 1 \mathrm{H}), 5.05(\mathrm{~s}, 2 \mathrm{H}) .{ }^{13} \mathrm{C}$ NMR $(151 \mathrm{MHz}, \mathrm{DMSO}) 8192.66(\mathrm{~s}), 136.97(\mathrm{~s}), 134.21(\mathrm{~s})$, $131.71(\mathrm{~s}), 131.06(\mathrm{~s}), 130.21(\mathrm{~s}), 127.56(\mathrm{~s}), 49.18(\mathrm{~s}), 40.08-39.94(\mathrm{~m}), 39.92(\mathrm{~s}), 39.71$ (d, J = $21.0 \mathrm{~Hz})$, 39.51-39.35 (m), 39.35-39.30 (m), $39.22(\mathrm{~s}), 39.08(\mathrm{~s})$.

The obtained substrate and product were subjected to HPLC analysis. HPLC analyses for 2-chloro-1-(2,4-dichlorophenyl) ethanone and (R)-2-chloro-1-(2,4-dichlorophenyl) ethanol were performed on an LC-20A system (Shimadzu) combined with an SPD-20A UV detector (Shimadzu); 
The conditions were: Column of Daicel Chiralpak®OB-H $(250 \mathrm{~mm} \times 4.6 \mathrm{~mm}$ i.d., particle size $5 \mu \mathrm{m}$, Daicel Chemical Ltd., Tokyo, Japan), mobile phase of isopropanol-n-hexane buffer (3:97, v/v), flow rate of $1.0 \mathrm{~mL} \mathrm{~min}{ }^{-1}$, and in the wavelength of $220 \mathrm{~nm}$.

$$
\text { Yield }(\%)=\frac{C p}{C 0} \times 100 \%
$$

In the formula, $\mathrm{C}_{p}$ is the concentration of the resultant $(R)$-2-chloro-1-(2,4-dichlorophenyl) ethanol, and $\mathrm{C}_{0}$ is the initial concentration of 2-chloro-1-(2,4-dichlorophenyl) ethanone.

$$
\text { ee }=\frac{C_{S}-C_{R}}{C_{S}+C_{R}} \times 100 \%
$$

In the formula, $C_{S}$ is the resultant concentration of (S)-2-chloro-1-(2,4-dichlorophenyl) ethanol; $C_{R}$ is the resultant concentration of ( $R$ )-2-chloro-1-(2,4-dichlorophenyl) ethanol.

\subsection{The Effects of Key Variables on the Asymmetric Reduction}

In the quest for enhancing the ability of asymmetric reductions, the cosubstrates, glycerol addition, buffer $\mathrm{pH}$, temperature, cell concentration, substrate concentration, and reaction time were optimized. The yield and product ee were assayed by HPLC analysis.

\subsubsection{Effect of Different Cosubstrates on the Asymmetric Reduction}

The results are shown in Table 2. The reaction conditions were: $100 \mathrm{~g} / \mathrm{L}$ wet cell weight, $10 \mathrm{~mL}$ of phosphate buffer [0.1 M, pH 6.5, DMSO $(10 \%, v / v)], 2 \mathrm{~g} / \mathrm{L}$ of 2-chloro-1-(2,4-dichlorophenyl) ethanone, and different cosubstrates at a fraction of $10 \%(w / v$, or $v / v)$, at $30{ }^{\circ} \mathrm{C}$ and $200 \mathrm{rpm}$ for $24 \mathrm{~h}$.

\subsubsection{Effect of Different Glycerol Addition on the Asymmetric Reduction}

The optimized results of glycerol addition are revealed in Figure 5. The reaction conditions are: $100 \mathrm{~g} / \mathrm{L}$ Acinetobacter sp. ZJPH1806 cells, $10 \mathrm{~mL}$ of phosphate buffer [0.1 M, pH 6.5, DMSO (10\%, $v / v)]$, and $2 \mathrm{~g} / \mathrm{L}$ of 2-chloro-1-(2,4-dichlorophenyl) ethanone, using glycerol as the cosubstrate, with a proportion of $5 \%$ to $25 \%(w / v)$, at $30{ }^{\circ} \mathrm{C}$ and $200 \mathrm{rpm}$ for $24 \mathrm{~h}$.

\subsubsection{Effects of Buffer $\mathrm{pH}$ and Ionic Strength on the Asymmetric Reduction}

In the phosphate buffer system, $\mathrm{pH}$ and ionic strength are optimized and the results are shown in Table 3. The reaction conditions are: $100 \mathrm{~g} / \mathrm{L}$ Acinetobacter sp. ZJPH1806 cells, $10 \mathrm{~mL}$ of phosphate buffer [DMSO $(10 \%, v / v)], 2 \mathrm{~g} / \mathrm{L}$ of 2-chloro-1-(2,4-dichlorophenyl) ethanone, and 20\% (w/v) glycerol, at $200 \mathrm{rpm}$ and $30^{\circ} \mathrm{C}$, with a $24 \mathrm{~h}$ reduction time.

\subsubsection{Effect of Temperature on the Asymmetric Reduction}

The optimized results of temperature are outlined in Figure 6. Reaction conditions: $100 \mathrm{~g} / \mathrm{L}$ Acinetobacter sp. ZJPH1806 cells, $10 \mathrm{~mL}$ of phosphate buffer [0.1 M, pH 7.6, DMSO (10\%, v/v)], $2 \mathrm{~g} / \mathrm{L}$ of 2-chloro-1-(2,4-dichlorophenyl) ethanone, and 20\% (w/v) glycerol, at $200 \mathrm{rpm}$, and at different temperatures (from $25^{\circ} \mathrm{C}$ to $50^{\circ} \mathrm{C}$ ) for $24 \mathrm{~h}$.

4.8.5. Optimization of Cell Concentration, Substrate Concentration, and Reaction Time on the Asymmetric Reduction

Cell concentration, substrate concentration, and reaction time are optimized, and the results are shown in Figure 7. The reaction conditions are: $10 \mathrm{~mL}$ of phosphate buffer [0.1 M, pH 7.6, DMSO (10\%, $v / v)$ ], 20\% (w/v) glycerol, and $2 \mathrm{~g} / \mathrm{L}$ of 2-chloro-1-(2,4-dichlorophenyl) ethanone (a) at $200 \mathrm{rpm}$ and $40^{\circ} \mathrm{C}$ for $24 \mathrm{~h}(\mathrm{a}, \mathrm{b})$. 


\section{Conclusions}

In the present study, a biological method used to produce $(R)$-2-chloro-1-(2,4-dichlorophenyl) ethanol with Acinetobacter sp. ZJPH1806 was successfully developed. The findings were that of achieving the desired product in a single step by the whole-cell method. This study also provides a useful strategy to develop efficient and economical approach to cofactor regeneration. Glycerol was selected as an economical and environmentally friendly cosubstrate. Therefore, the reaction did not depend on any additional coenzyme, and the cost of the biological process was reduced. Meanwhile, the reaction was in an aqueous medium at mild conditions and the subsequent treatment was simple. The results indicated that Acinetobacter sp. ZJPH1806 containing a thermophilic carbonyl reductase is a promising biocatalyst for the production of the chiral intermediates and possessing a wide $\mathrm{pH}$ range for asymmetric reduction. Although biosynthesis efficiency of $(R)$-2-chloro-1-(2,4-dichlorophenyl) ethanol was considerably improved in the current research, similarly, the problem of substrate inhibition is a limiting factor. Thus, the research on medium engineering for biocatalysis or the immobilization of the enzyme-containing cells are important subjects worthy of further study to improve the efficiency of this biological process.

Supplementary Materials: The following are available online at http://www.mdpi.com/xxx/s1, Figure S1: The results of the bioconverted sample by HPLC analysis, Figure S2: The colony morphology of ZJPH1806, Figure S3: The phylogenetic tree of Acinetobacter sp. ZJPH1806, Figure S4: The ${ }^{1} \mathrm{H}$ NMR spectrum of the substrate.

Author Contributions: Conceptualization, P.W.; methodology, P.W.; software, Y.M.; validation, Y.M.; investigation, Y.M.; resources, P.W.; data curation, Y.M.; writing—original draft preparation, Y.M.; writing—review and editing, Y.M. and P.W.; visualization, Y.H. and Y.L.; project administration, P.W.

Funding: This work was funded by the National Natural Science Foundation of China (No. 21676250), and the Zhejiang Provincial Natural Science Foundation of China (LY16B060010).

Conflicts of Interest: The authors declare no conflict of interest. The funders had no role in the design of the study; in the collection, analyses, or interpretation of data; in the writing of the manuscript, or in the decision to publish the results.

\section{References}

1. Giraud, F.; Loge, C.; Pagniez, F.; Crepin, D.; Pape, P.L.; Borgne, M.L. Design, synthesis, and evaluation of 1-(N-benzylamino)-2-phenyl-3-(1H-1,2,4-triazol-1-yl)propan-2-ols as antifungal agents. Bioorg. Med. Chem. Lett. 2008, 18, 1820-1824. [CrossRef] [PubMed]

2. Mangas-Sanchez, J.; Busto, E.; Gotor-Fernandez, V.; Malpartida, F.; Gotor, V. Asymmetric chemoenzymatic synthesis of miconazole and econazole enantiomers. The importance of chirality in their biological evaluation. J. Org. Chem. 2011, 76, 2115-2122. [CrossRef] [PubMed]

3. Barasch, A.; Griffin, A.V. Miconazole revisited: New evidence of antifungal efficacy from laboratory and clinical trials. Future Microbiol. 2008, 3, 265-269. [CrossRef] [PubMed]

4. Fonseca, T.S.; Lima, L.D.; Oliveira, M.C.F.; Lemos, T.L.G.; Zampieri, D.; Molinari, F.; Mattos, M.C. Chemoenzymatic synthesis of luliconazole mediated by lipases. Eur. J. Org. Chem. 2018, 2018, 2110-2116. [CrossRef]

5. Zhang, X. Industrial Production Method of Chiral 2-Chloro-1-(2,4-dichlorophenyl)ethanol. C.N. Patent 106008166 A, 12 October 2016.

6. Luo, J.Y.; Xu, X.B.; Guo, P. New Synthetic Method for Key Chiral Intermediates of Luliconazole. C.N. Patent 108299156 A, 20 January 2018.

7. Shang, Y.P.; Chen, Q.; Kong, X.D.; Zhang, Y.J.; Xu, J.H.; Yu, H.L. Efficient synthesis of (R)-2-chloro-1-(2,4-dichlorophenyl) ethanol with a ketoreductase from Scheffersomyces stipitis CBS 6045. Adv. Synth. Catal. 2017, 359, 426-431. [CrossRef]

8. Grynkiewicz, G.; Borowiecki, P. New applications of biotechnology in the field of pharmaceutical syntheses. Przem. Chem. 2019, 98, 434-441.

9. Xie, Y.; Xu, J.H.; Xu, Y. Isolation of a Bacillus strain producing ketone reductase with high substrate tolerance. Bioresour. Technol. 2010, 101, 1054-1059. [CrossRef] 
10. Lin, H.; Chen, Y.Z.; Xu, X.Y.; Xia, S.W.; Wang, L.X. Preparation of key intermediates of adrenergic receptor agonists: Highly enantioselective production of $(R)-\alpha$-halohydrins with Saccharomyces cerevisiae CGMCC 2.396. J. Mol. Catal. B Enzym. 2009, 57, 1-5. [CrossRef]

11. Xie, Y.; Xu, J.H.; Lu, W.Y.; Lin, G.Q. Adzuki bean: A new resource of biocatalyst for asymmetric reduction of aromatic ketones with high stereoselectivity and substrate tolerance. Bioresour. Technol. 2009, 100, 2463-2468. [CrossRef]

12. Tang, Y.P.; Ding, G.F.; Yu, F.M.; Yang, Z.S.; Huang, F.F. A Method for Biosynthesis of Intermediates of Miconazole. C.N. Patent 108396040 A, 14 August 2018.

13. Ferreira-Leitão, V.S.; Cammarota, M.C.; Aguieiras, E.C.G.; de Sá, L.R.V.; Fernandez-Lafuente, R.; Freire, D.M.G. The protagonism of biocatalysis in green chemistry and its environmental benefits. Catalysts 2017, 7, 9.

14. Hollmann, F.; Arends, I.W.C.E.; Holtmann, D. Enzymatic reductions for the chemist. Green Chem. 2011, 13, 2285-2313. [CrossRef]

15. Sahin, E.; Serencam, H.; Dertli, E. Whole cell application of Lactobacillus paracasei BD101 to produce enantiomerically pure (S)-cyclohexyl(phenyl) methanol. Chirality 2019, 31, 211-218. [CrossRef]

16. Vitale, P.; Perna, F.M.; Agrimi, G.; Scilimati, A.; Salomone, A.; Cardellicchioe, C.; Capriati, V. Asymmetric chemoenzymatic synthesis of 1,3-diols and 2,4-disubstituted aryloxetanes by using whole cell biocatalysts. Org. Biomol. Chem. 2016, 14, 11438-11445. [CrossRef]

17. Kara, S.; Schrittwieser, J.H.; Hollmann, F.; Ansorge-Schumacher, M.B. Recent trends and novel concepts in cofactor-dependent biotransformations. Appl. Microbiol. Biotechnol. 2014, 98, 1517-1529. [CrossRef]

18. Gu, Y.L.; Jerome, F. Glycerol as a sustainable solvent for green chemistry. Green Chem. 2010, 12, 1127-1138. [CrossRef]

19. Asami, K.; Machida, T.; Jung, S.; Hanaya, K.; Shoji, M.; Sugai, T. Synthesis of (R)-bambuterol based on asymmetric reduction of 1-[3,5-bis(dimethylcarbamoyloxy)phenyl]-2-chloroethanone with incubated whole cells of Williopsis californica JCM 3600. J. Mol. Catal. B Enzym. 2013, 97, 106-109. [CrossRef]

20. Sun, J.; Huang, J.; Ding, X.Z.; Wang, P. Efficient enantioselective biocatalytic production of a chiral intermediate of sitagliptin by a newly filamentous fungus isolate. Appl. Biochem. Biotechnol. 2016, 180, 695-706. [CrossRef]

21. Guo, Z.W.; Chen, Y.J.; Goswami, A.; Hanson, R.L.; Patel, R.N. Synthesis of ethyl and $t$-butyl $(3 R, 5 S)$-dihydroxy-6-benzyloxy hexanoates via diastereo- and enantioselective microbial reduction. Terahedron Asymmetry 2006, 17, 1589-1602. [CrossRef]

22. Zhang, Y.J.; Chen, J.L.; Chen, C.S.; Wu, S.J. Isolation of a Bacillus Aryabhattai strain for the resolution of $(R, S)$-ethyl indoline-2-carboxylate to produce (S)-indoline-2-carboxylic acid. Catalysts 2019, 9, 206. [CrossRef]

23. Wang, S.S.; Xu, Y.; Zhang, R.Z.; Zhang, B.T.; Xiao, R. Improvement of (R)-carbonyl reductase-mediated biosynthesis of $(R)-1$-phenyl-1,2-ethanediol by a novel dual-cosubstrate-coupled system for NADH recycling. Process Biochem. 2012, 47, 1060-1065. [CrossRef]

24. Simon, R.C.; Mutti, F.G.; Kroutil, W. Biocatalytic synthesis of enantiopure building blocks for pharmaceuticals. Drug. Discov. Today Technol. 2013, 10, e37-e44. [CrossRef]

25. Zhu, D.M.; Hyatt, B.A.; Hua, L. Enzymatic hydrogen transfer reduction of $\alpha$-chloro aromatic ketones catalyzed by a hyperthermophilic alcohol dehydrogenase. J. Mol. Catal. B Enzym. 2009, 56, $272-276$. [CrossRef]

26. Wachtmeister, J.; Rother, D. Recent advances in whole cell biocatalysis techniques bridging from investigative to industrial scale. Curr. Opin. Biotechnol. 2016, 42, 169-177. [CrossRef]

27. Goldberg, S.; Guo, Z.W.; Chen, S.; Goswami, A.; Patel, R.N. Synthesis of ethyl-(3R,5S)-dihydroxy-6-benzyloxyhexanoates via diastereo- and enantioselective microbial reduction: Cloning and expression of ketoreductase III from Acinetobacter sp. SC 13874. Enzym. Microb. Technol. 2008, 43, 544-549. [CrossRef]

28. Wu, X.R.; Liu, N.; He, Y.M.; Chen, Y.J. Cloning, expression, and characterization of a novel diketoreductase from Acinetobacter baylyi. Acta Biochim. Biophys. Sin. 2009, 41, 163-170. [CrossRef]

29. Atalah, J.; Cáceres-Moreno, P.; Espina, G.; Blamey, J.M. Thermophiles and the applications of their enzymes as new biocatalysts. Bioresour. Technol. 2019, 280, 478-488. [CrossRef]

(C) 2019 by the authors. Licensee MDPI, Basel, Switzerland. This article is an open access article distributed under the terms and conditions of the Creative Commons Attribution (CC BY) license (http://creativecommons.org/licenses/by/4.0/). 